DOI: https://doi.org/10.34069/AI/2021.47.11.19

How to Cite:

Kuznietsov, S. (2021). Status «ecological» obligations of a flag state as an integral part of the «genuine link» conception. Amazonia Investiga, 10(47), 190-196. https://doi.org/10.34069/AI/2021.47.11.19

\title{
Status «ecological» obligations of a flag state as an integral part of the «genuine link» conception
}

\section{Статусні «екологічні» зобов'язання «держави прапора», як невід'ємна частина концепції «реального зв'язку»}

Received: October 10, 2021

The modern legal regime of a flag State's status "ecological" obligations is composed by a legislation (laws and regulations) of two levels: international and national. The legislation of both the levels is consistent with the generally accepted international rules, standards and recommended practices and procedures, the "UNCLOS'82", the rights of States and prescribes, inter alia, measures to be taken for the protection and preservation of the marine environment pollution - measures to prevent, reduce and control pollution of the marine environment - the States' "ecological" obligations. It is generally accepted in international maritime law to dived abovementioned obligations in: status "ecological" obligations of the "shore States", status "ecological" obligations of the "port States" and status "ecological" obligations of the "flag States". The research topic is certainly relevant given the almost catastrophic situation due to pollution of the world's oceans and the environment in general. The research methodology includes methods of analysis and synthesis, dogmatic method and comparative law method. This research focuses on the definition of the modern international legal regime of a flag State's status "ecological" obligations. These obligations form a flag State's legal status and could be qualified as an integral part of the "genuine link" conception. The author of the article concluded that the current conventions in the field of maritime law aimed at protecting the world's oceans play an important role, but no less important tasks are to improve national legislation of coastal countries, as well as proper implementation of both international and
Accepted: November 20, 2021

Written by:

Serhii Kuznietsov ${ }^{83}$

https://orcid.org/0000-0002-8607-6414

\section{Анотація}

Сучасний правовий режим «екологічних» зобов'язань держави прапора складається із законодавства (законів і правил) двох рівнів: міжнародного та національного. Законодавство обох рівнів відповідає загальновизнаним міжнародним правилам, стандартам i рекомендованим практикам i процедурам, «UNCLOS'82», правам держав і передбачає, зокрема, заходи, які необхідно вживати для захисту та збереження забруднення морського середовища «екологічні» зобов'язання держав. У міжнародному морському праві загальноприйнято розглядати вищезгадані зобов'язання: статусні «екологічні» зобов'язання «берегових держав», статус «екологічних» зобов' язань «держав порту» та статус «екологічних» зобов'язань «держав прапора». Досліджувана тематика $\epsilon$ безумовно актуальною 3 огляду на майже катастрофічну ситуацію у зв'язку із забрудненням світового океану, i навколишнього природного середовища загалом. Методологія дослідження включає методи аналізу і синтезу, догматичний метод i порівняльно-правовий метод. Це дослідження зосереджено на визначенні сучасного міжнародно-правового режиму статусу «екологічних» зобов'язань держави прапора. Ці зобов'язання утворюють правовий статус держави прапора і можуть бути кваліфіковані як невід'ємна частина концепції «справжнього зв'язку». Автор статті дійшов висновку, що чинні конвенції у галузі морського права, спрямовані на захист світового океану, виконують важливу роль, втім не менш важливими завданнями $€$ удосконалення національного законодавства

\footnotetext{
${ }^{83} \mathrm{PhD}$ in Political Sciences, Director of the Seafarers Training Centre, Ukraine.
} 


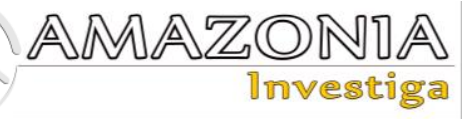

national norms aimed at the protection and restoration of the world's oceans.

Keywords: ecological obligations, «shore states», MARPOL, United Nations, international convention.

\section{Introduction}

In the contemporary epoch the problems of the exploration, development and use of the ocean spaces' resources have acquired a global character exerting a noticeable influence on the general progress of international relations and affecting the interests of all states. There are international conventions with direct or indirect implications for preventing of marine pollution, which are illustrated the interrelations of marine safety, marine pollution and international maritime law and, thus, have formed modern international legal regime of statute "ecological" obligations of States Parties to the conventions and, inter alia, flag States. The main responsibility for compliance of ships with generally accepted international rules and standards fixed in appropriate conventions adopted under the aegis of IMO or in other way rests with "flag States", which for these purposes shall insure compliance with applicable international rules and standards of "vessels flying their flag or of their registry" - "flag vessels". A profound analyze of these conventions is assuming special significance these conventions are an important step towards codification and progressive development of the current international law of the sea for the purpose of providing a solid basis for the enforcement of appropriate rules and regulations pertaining to the ocean spaces to meet the new political and socio-economic conditions of life and pressures of the scientific and technological revolution. Given the conventions' forthcoming entry into force, it is important to study its provisions and to work out scientific recommendations as to their implementation.

It is a well-known fact that there are some international conventions with direct or indirect implications for preventing of marine pollution. The relatively brief listing of this conventions is illustrated the interrelations of marine safety, marine pollution and international maritime law and, thus, have formed modern international legal regime of statute "ecological" obligations of States Parties to the conventions. прибережних країн, а також належне виконання як міжнародних, так i національних норм, спрямованих на захист i відновлення світового океану.

Ключові слова: екологічні зобов'язання, «прибережні держави», МАРПОЛ, Організація об'єднаних націй, міжнародна конвенція.

The International Convention for the Prevention of Pollution from Ships (generally known as "MARPOL") (International Maritime Organization, 2005) is among the conventions with direct implications for preventing of marine pollution from ships (MARPOL). For the first time, on conclusion in 1973, "MARPOL" was named "MARPOL'73", and then in 1978, after conclusion of the Protocol (generally known as the "Tanker Safety and Pollution' Protocol") "MARPOL" was titled "MARPOL'73/78" (International Maritime Organization, 1997). After conclusion in 1997 of a new Protocol, which will come into force on 29th January, 2010, Marine Environment Protection Committee (MEPC) (International Maritime Organization, 1973) in 2007 (International Maritime Organization, 2007) decided "to make use of the approved short titles in meeting documents and communications where the formal title of a convention, protocol or mandatory instrument need not be quoted in full" and to title the convention "MARPOL" (see References). The Parties to the "MARPOL" have adopt this international agreement, "being conscious the need to preserve the human environment in general and the marine environment in particular", recognizing that "deliberate, negligent or accidental release of oil and other harmful substances from ships constitutes a serious source of pollution", desiring "to achieve the complete elimination of intentional pollution of the marine environment by oil and other harmful substances and the minimization of accidental discharge of such substances" and have agreed that "the Parties to the Convention undertake to give effect to the provisions of the present Convention and those Annexes thereto by which they are bound, in order to prevent the pollution of the marine environment by the discharge of harmful substances or effluents containing such substances in contravention of the Convention ("MARPOL". Article 1 "General obligations under the Convention", paragraph (1). It was declared (see "MARPOL". Article 9. "Other treaties and interpretation") that "nothing in the 
present Convention shall prejudice the codification and development of the law of the sea by the United Nations Conference on the Law of the Sea convened pursuant to resolution 2750 C(XXV) of the General Assembly of the United Nations (UN, 1970) nor the present or future claims and legal views of any State concerning the law of the sea and the nature and extent of coastal and flag State jurisdiction ("MARPOL". Art. 9, paragraph 2); the term "jurisdiction" in the present Convention "shall be construed in the light of international law in force at the time of application or interpretation of the present Convention ("MARPOL". Art. 9, paragraph 3).

The United Nations Convention on the Law of the Sea (generally known as "UNCLO'82") is among the conventions with universal implication for preventing the marine pollution (UNCLOS'82). Upon entering into force in 1994 "UNCLOS'82" had become "the most important factor of universal cooperation" in the abovementioned sphere (Burdzhanadze, 1997, p. 12). Every State which have ratified "UNCLOS'82" obtain certain subjective rights, juridical obligations and responsibilities and, therefore, legal status - State Party - "state, which have consented to be bound by this Convention and for which this Convention is in force" ("UNCLOS'82". Part I "Introduction". Article 1 "Use of terms and scope", paragraph 2 (1). Thus, States Parties "shall fulfil in good faith the obligations assumed" under "UNCLOS'82" and "shall exercise the rights, jurisdiction and freedoms" recognized in this Convention in a manner which would not constitute an abuse of right ("UNCLOS'82". Part XVI. "General Provisions". Article 300 "Good faith and abuse of rights"). It must be noted that "UNCLOS' 82 " shall not "alter the rights and obligations of States Parties which arise from other agreements", but those compatible with this Convention and which do not affect the enjoyment by other States Parties of their rights or the performance of their obligations under this Convention ("UNCLOS'82". Part XVI. Article 311 "Relation to other conventions and international agreements"). With regard to other conventions on the protection and preservation of the marine environment the provisions of Part XII. "Protection and preservation of the marine environment" ("UNCLOS'82". Section 11. "Obligations under other conventions on the protection and preservation of the marine environment") are without prejudice to the specific obligations assumed by States under special conventions and agreements concluded previously which relate to the protection and preservation of the marine environment and to agreements which may be concluded in furtherance of the general principles set forth in "UNCLOS'82" (Article 237 "Obligations under other conventions on the protection and preservation of the marine environment", paragraph 2) and specific obligations assumed by States under special conventions on the matter "should be carried out in a manner consistent with the general principles and objectives" of "UNCLOS'82" (Art. 237, paragraph 2). Article 192 "General obligation" ("UNCLOS'82". Part XII. Section 1. "General provisions") prescribes that States Parties "have the obligation to protect and preserve the marine environment". But, notwithstanding, that States "have the sovereign right to exploit their natural resources pursuant to their environmental policies", they must realize its sovereign right "in accordance with their duty to protect and preserve the marine environment" (“UNCLOS'82". Art. 193).

So, "there is no question that the regulatory umbrella" provided by international instruments "is complex as well as significant" and that knowledge of the basic provisions and intent of the conventions must be mandatory today for all with direct responsibility for ship operation" (Gold, 1985, p. 51), inter alia, especially for the "flag States".

\section{Theoretical Framework or Literature Review}

The scientific and theoretical basis of the topic under study is the works of scientists, theorists, and practitioners in the field of the Law of the Sea.

Tamara Ioseliani (2015) in her research paper "Generally Accepted International Rules, Regulations, Procedures and Practices in accordance with the United Nations Convention on the Law of the Sea 1982 and the IMO Mandatory Instruments in Regards Maritime Safety" analyzes the existence of a link between LOSC and the IMO and their respective roles in the process of effective administration of maritime, sea and ocean governance issues.

Jan Jakub Solski in his research paper "The Genesis of Article 234 of the UNCLOS" (2021) examines the circumstances under which Article 234 of UNCLO was adopted. The provisions of the article 234 allow the coastal state to independently determine in its legislation the rules for the prevention, reduction and control of pollution from the vessel.

Adriana Abril Ortiz, Dolores Sucozhañay, Paul Vanegas and Andrés Martínez-Moscoso in their 


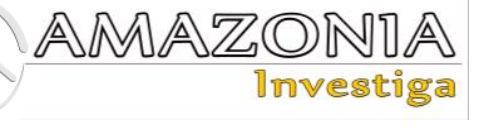

article "A Regional Response to a Global Problem: Single Use Plastics Regulation in the Countries of the Pacific Alliance" (2020) made a thorough analysis of the national legislation of Mexico, Colombia, Chile, Peru and Ecuador in the field of combating marine pollution with plastic waste. Based on the results of the study, it was concluded that the legal regulation of the studied relations is insufficient and the need to improve regulations aimed at limiting plastic pollution of the sea.

Professor Finn Arnesen and Professor Tarjei Bekkedal (2019) in their book "Fair wage and working conditions within the European Maritime Space", in particular, present recommendations on the basis of which the European Maritime Space can be built.

Miguel Ángel Franco García (2014) in his article "Underwater Noise Pollution: Special Reference to the Impact on Cetaceans Produced by the Sonars of Warships" touches upon the problems of protection of marine animals from noise of anthropogenic origin. In this regard, the article examines a number of international and national regulations aimed at ensuring this protection.

Álvaro Gómez (2016) in his scientific paper "Safety at sea" researches the problems of ensuring the safety of people at sea. In this regard, the basic international conventions in the field of safety of crews and passengers of ships and other persons at sea are analyzed.

Pura C. Roy (2020), the author of the article "Dangers that lurk in the sea. Spills and oil slicks", examines the main international conventions on the protection of the sea from man-made pollution from ships. The author of the article focuses mainly on combating pollution of the world's oceans with petroleum products.

\section{Methodology}

The research methodology includes, first of all, general philosophical methods of analysis and synthesis, as well as special methods of scientific cognition - dogmatic and comparative law method.

Thus, the method of analysis provided an opportunity for the authors of the article to explore the full range of regulations, both internationally and nationally, governing the environmental obligations of states to limit pollution of the world's oceans. The method of synthesis provided an opportunity to explore in unity all aspects of the international legal regime of statutory environmental obligations enshrined in international conventions on the law of the sea. Furthermore, the dogmatic method was used to study international conventions and national regulations governing the obligations of states in the field of maritime law and in terms of obligations to prevent pollution of marine areas in particular. It is the dogmatic method involves the study of law as such, in "pure form", out of connection with other social phenomena. Its purpose is to analyze the current legislation and the practice of its application by intergovernmental associations, international organizations, government agencies, to identify external, obvious aspects of legal phenomena without penetrating the internal substantive aspects and ties. Accordingly, the dogmatic method became the basis for this study.

As for the comparative-legal method, it allowed to see the main international law and national acts governing the studied relations. Comparative method is a purposeful application of comparison to achieve a certain goal; it is a relatively independent, organized way of research necessary to achieve cognitive goals. The comparative method in the scientific literature is interpreted as a method of determining the unknown by comparison with the known; the method of determining the qualities or properties of a phenomenon by comparing it with other qualities or properties or with the qualities or properties of another phenomenon; the method of establishing patterns by comparing objects at different times, comparing their properties in the past with the same properties in the current state to identify changes or trends; a method of studying similarities and differences in order to establish classifications and typologies of social phenomena, as well as testing hypotheses about random relationships by studying the empirical relationship and the temporal sequence of factors. The comparative law method made it possible to compare the provisions of the main international conventions on the law of the sea and to conclude that it is necessary to improve certain aspects of these regulations.

\section{Results and Discussion}

In the present times development and use of the World Ocean have acquired a global character exerting a noticeable influence on the general progress of international relations and affecting the interests of all states. Efficient utilization of the World Ocean as well as the exploitation of its resources "largely depend on the legal status of the sea areas", i.e. all those waters where ships 
are sailed, or activities are underway to protect and exploit the natural resources (Kolodkin, Kiselev, \& Savaskov, 1984; Carty, 1991). The history of the Law of the Sea is, "first and foremost" a history of the regulation of shipping law and the utilization of the resources of seas and oceans. For many centuries it has been the basis for the creation of various conventional and customary norms regulating shipping in the high seas (Uzunov, 1984; Parkinson, 1991). The "UNCLOS'82" "was designed to settle most of problems that have arisen in the modern international law of the sea, including those of "protection and preservation of the marine environment and the responsibilities of "flag of the ship' State" are given in more detail" (Ivanov, 1984). The "UNCLOS'82" deals with the protection and preservation of marine environment from all possible forms of pollution arising from human activities but the greatest attention is paid to the prevention of pollution from vessels (Sapozhnikov, 1984). The main responsibility for compliance of ships with generally accepted international rules and standards fixed in appropriate conventions adopted under the aegis of IMO or in other way rests with "flag States" which for these purposes shall insure compliance with applicable international rules and standards (established mainly by IMO) by "vessels flying their flag or of their registry" - "flag vessels". The "UNCLOS'82" prescribes that States shall cooperate on a global basis and, as appropriate, on a regional basis, directly or through competent international organizations (Part XII. Section 2. Global and regional cooperation).

International rules on preventing pollution of marine environment, including those from ships, were analyzed by many researchers (see scientific works of Sapozhnikov (1984), Kiselev (1986). It is generally accepted that the national legislation "has an important meaning" for the struggle with the pollution of marine environment (Kiselev, 1975). The national legal measures for marine environment protection were investigated by Sapoznikov (1984c) relating to the USSR and other socialist countries; and Golovatiy (1984) - relating to developing countries.

Section 5 of the Part XII of the "UNCLOS'82" (Part XII. Section 5. International rules and national legislation to prevent, reduce and control pollution of the marine environment) prescribes that the States Parties shall, acting through the competent international organization or general diplomatic conference:
1) establish international rules and standards for the "PRC" of the "MEP" from vessels and promote the adoption of routeing systems designed to minimize the threat of accidents which might cause the "MEP", including the coastline, and pollution damage to the related interests of coastal States (Article 211 "Pollution from ships", paragraph 1);

2) adopt laws and regulations for the "PRC" of the "MEP" from "flag vessels" (vessels flying their flag or of their registry). Such laws and regulations shall at least have the same effect as that of generally accepted international "PRC" established through the competent international organization or general diplomatic conference (Art. 211, paragraph 2). For the purposes of the "MARPOL" "Organization" means the Inter-Governmental Maritime Consultative Organization" - further International Maritime Organization ("MARPOL". Art. 2, paragraph 7).

3) require the master of a "flag vessel", to furnish, upon the request of shore State, information as to whether it is proceeding to a State and, if so, to indicate whether it complies with the port entry requirements of that State (Art. 211, paragraph 3);

4) adopt laws, regulations and take other measures, as may be necessary to the "PRC" of the "MEP" by dumping, and shall endeavour to establish global and regional "RSaRPP" to the "PRC" of the "MEP" by such pollution (Article 210 "Pollution by dumping").

5) adopt laws, regulations and take other measures to the "PRC" of the "MEP" from or through the atmosphere, applicable to the air space under their sovereignty and to vessels flying their flag or of their registry, taking into account internationally agreed "RSaRPP" and shall endeavour to establish global and regional "RSaRPP" to the "PRC" of the "MEP" from or through the atmosphere.

Researchers of the prevention of marine environment from or through the atmosphere problems by means of international law regulation note that the main problem of the matter is "to limit, as maximum as possible, the harmful influence on its elements" (Vinogradov, 1987), thus they tell about "the complex of measures", which are dedicated to preservation of "natural chemical composition of atmospheric air" (where "air" means sum of gases, which compose the Earth's atmosphere), to preventing of its pollution by the "emissions of 


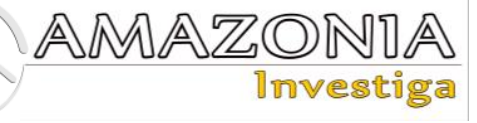

anthropological nature" (Magerramov, 2010), p. 14).

Section 6 of the Part XII of the "UNCLOS'82" (Part XII. Section 6. Enforcement) prescribes that States Parties shall adopt laws and regulations in accordance with the "UNCLOS'82" and applicable international rules and standards, established through competent international organizations or diplomatic conference, for the "PRC" of the "MEP" from the "flag vessels" and shall accordingly adopt laws and regulations and take other measures necessary for their implementation, which shall be enforced by the flag State with regard to the "flag vessels".

\section{Conclusions}

The world community must realize that the preservation and restoration of the world's oceans requires joint painstaking work. International conventions should play a leading role in coordinating international activities of all the world powers involved to protect the world's water resources.

Thus, it should be emphasized that today there is no doubt that the "regulatory umbrella" provided by international instruments is complex and significant, and that knowledge of the basic principles and intentions of the basic international conventions should be mandatory today for all those powers who have direct responsibility for the operation of ships and, in particular, for the "flag states".

\section{Bibliographic references}

Arnesen, F., \& Bekkedal, T. (2019). Fair wage and working conditions within the European Maritime Space. Oslo: Scandinavian Institute of Maritime Law. https://www.jus.uio.no/nifs/forskning/publik asjonar/artiklar/arnesen-bekkedal-europeanmaritime-space-october-2019.pdf

Burdzhanadze, N.A. (1997). Legal matters of marine environment protection: UN Convention on the Law of the Sea and Bucharest Convention on the Black Sea Pollution Protection. Soviet Yearbook of Maritime Law, 3, 11 - 16.

Carty, A. (1991). Reason and rhetoric: legal discourse and the common heritage of mankind in the resources of the seabed. Moscow: Mortekhine advertising.

Franco García, M.Á. (2014). Underwater Noise Pollution: Special Reference to the Impact on Cetaceans Produced by the Sonars of
Warships. Actualidad Jurídica Ambiental, 33, 34-59,

https://dialnet.unirioja.es/servlet/articulo?co digo $=5666011$

Gold, E. (1985). Handbook on Marine Pollution. Norway: Nick Facer Publishing.

Golovatiy, S.P. (1984). National legal measures of marine environment protection. Kyiv: Nauk. dumka.

Gómez, Á. (2016). Safety at Sea. AENOR: Revista de la normalización y la certificación, 317 , 36-39. https://dialnet.unirioja.es/servlet/articulo?co digo $=5603514$

International Maritime Organization (IMO). (1973). Establishment of the Marine Environment Protection Committee: Resolution A.297(VIII). https://wwwcdn.imo.org/localresources/en/K nowledgeCentre/IndexofIMOResolutions/As semblyDocuments/A.297(8).pdf

International Maritime Organization (IMO). (1973). International Convention for the Prevention of Pollution from Ships, ["MARPOL'73"].

http://www.mar.ist.utl.pt/mventura/ProjectoNavios-I/IMO-

Conventions\%20\%28copies\%29/MARPOL. pdf

International Maritime Organization (IMO). (1997). Protocol of 1997 to Amend the International Convention for the Prevention of Pollution from Ships [“MARPOL'73/78/97'].

http://www.mar.ist.utl.pt/mventura/ProjectoNavios-I/IMO-

Conventions\%20\%28copies\%29/MARPOL. pdf

International Maritime Organization (IMO). (2005). International Convention for the Prevention of Pollution from Ships. http://www.mar.ist.utl.pt/mventura/ProjectoNavios-I/IMO-

Conventions\%20\%28copies\%29/MARPOL. pdf

International Maritime Organization (IMO). (2007). Short titles of conventions and protocols. Report of the Marine Environmental Protection Committee on its fifty-sixth session (MEPC 56/14). http://www.crs.hr/Portals/0/docs/eng/imo_ia cs_eu/imo/mepc_reports/MEPC56.pdf

Ioseliani, T. (2015). Generally Accepted International Rules, Regulations, Procedures and Practices in accordance with the United Nations Convention on the Law of the Sea 1982 and the IMO Mandatory Instruments in Regards Maritime Safety. Georgia: The Nippon Foundation of Japan. 
https://www.un.org/oceancapacity/sites/ww w.un.org.oceancapacity/files/tamara_201512-18_final.pdf

Ivanov, G.G. (1984). Merchant shipping in the UN Convention on the Law of the Sea. Moscow: Mortekhine advertising.

Kiselev, V.A. (1975). The national legislation on preventing pollution of sea. Moscow: Transport.

Kiselev, V.A. (1986). Prevention of pollution by dumping. Moscow: Transport. http://lawlibrary.ru/izdanie12835.html

Kolodkin, A.L., Kiselev, V.A., \& Savaskov, P.V. (1984). Some provisions of the international legal status of the World Ocean in the light of the new UN Convention on the Law of the Sea. Moscow: Mortekhine advertising.

Magerramov, A.A. (2010). Preservation of the atmospheric air. International public and private law, 3(54), $14-16$.

Ortiz, A.A., Sucozhañay, D., Vanegas, P., \& Martínez-Moscoso, A. (2020). A Regional Response to a Global Problem: Single Use Plastics Regulation in the Countries of the Pacific Alliance. Sustainability, 12, 1-21. https://www.mdpi.com/20711050/12/19/8093/pdf
Parkinson, F. (1991). The genesis of the "Freedom of the Seas" as reflected in the history of the doctrine of international law. Moscow: Mortekhine advertising.

Roy, P.C. (2020). Dangers that Lurk in the Sea. Spills and Oil Slicks. Mediterráneo económico, 33, 253-267. https://dialnet.unirioja.es/servlet/articulo?co digo $=7663545$

Sapozhnikov, V.I. (1984). The international agreements on marine environment protection. Naukova dumka, 1, 8-21.

Solski, J.J. (2021). The Genesis of Article 234 of the UNCLOS. Ocean Development \& International Law, 52(1), 1-19. https://www.tandfonline.com/doi/full/10.108 0/00908320.2020.1835026

United Nations (1982). Convention on the Law of the Sea. https://www.un.org/depts/los/convention_ag reements/texts/unclos/unclos_e.pdf

Uzunov, D. (1984). Regime of navigation in the light of the 1982 UN Convention on the Law of the Sea. Moscow: Mortekhine advertising.

Vinogradov, S.V. (1987). International law and preservation of the atmosphere. Moscow: Nauka. 